\title{
Article \\ The Challenge of Environmental Samples for PCR Detection of Phytopathogenic Bacteria: A Case Study of Citrus Huanglongbing Disease
}

\author{
Félix Morán 1,+D, Silvia Barbé ${ }^{1,+}$, Saskia Bastin ${ }^{2}$, Inmaculada Navarro ${ }^{1}$, Edson Bertolini ${ }^{3}$, María M. López ${ }^{1}$, \\ Estrella Hernández-Suárez ${ }^{2}$, Alberto Urbaneja ${ }^{1}$ (D), Alejandro Tena ${ }^{1}$, Felipe Siverio ${ }^{2}$ and Ester Marco-Noales ${ }^{1, *}$ \\ 1 Instituto Valenciano de Investigaciones Agrarias (IVIA), Centro de Protección Vegetal y Biotecnología, \\ 46113 Valencia, Spain; moran_fel@gva.es (F.M.); barbe_sil@gva.es (S.B.); navarro_inmher@gva.es (I.N.); \\ lopez_margon@gva.es (M.M.L.); urbaneja_alb@gva.es (A.U.); tena_alebar@gva.es (A.T.) \\ 2 Instituto Canario de Investigaciones Agrarias (ICIA), Centro de Protección Vegetal y Biotecnología, \\ 38270 Canary Islands, Spain; sbastin@icia.es (S.B.); ehernand@icia.es (E.H.-S.); fsiverio@icia.es (F.S.) \\ 3 Faculdade de Agronomia, Universidade Federal do Rio Grande do Sul (UFRGS), \\ 91540-000 Porto Alegre, Brazil; edson.bertolini@ufrgs.br \\ * Correspondence: marco_est@gva.es \\ + Equal first author.
}

Citation: Morán, F.; Barbé, S.; Bastin S.; Navarro, I.; Bertolini, E.; López, M.M.; Hernández-Suárez, E.; Urbaneja, A.; Tena, A.; Siverio, F.; et al. The Challenge of Environmental Samples for PCR Detection of Phytopathogenic Bacteria: A Case Study of Citrus Huanglongbing Disease. Agronomy 2021, 11, 10. https:// dx.doi.org/10.3390/agronomy11010010

Received: 23 November 2020 Accepted: 21 December 2020

Published: 23 December 2020

Publisher's Note: MDPI stays neutral with regard to jurisdictional claims in published maps and institutional affiliations.

Copyright: (C) 2020 by the authors. Licensee MDPI, Basel, Switzerland. This article is an open access article distributed under the terms and conditions of the Creative Commons Attribution (CC BY) license (https: / / creativecommons.org/ licenses/by/4.0/).
Abstract: Huanglongbing (HLB) is the most devastating citrus disease and is associated with three bacterial species of the genus 'Candidatus Liberibacter' transmitted by insect vectors. The early detection of HLB is based on PCR methods, and it is one of the cornerstones for preventing incursion into disease-free countries. However, the detection of phytopathogenic bacteria with PCR-based methods is problematic in surveys that include a variety of samples of different origins. Here, we first report the proportion of amplifications obtained by two standardized real-time PCR methods for the diagnosis of HLB in various environmental samples that include plants, psyllid vectors, and parasitic wasps of the psyllids. The results of 4915 samples showed that $9.3 \%$ of them were amplified by the first rapid screening test and only $0.3 \%$ by the more specific tests. Most of the amplifications were associated with parasitic wasps. We designed the primers external to the target regions of both real-time PCR protocols to determine if amplifications belonged to one of three ' $\mathrm{C}$ a. Liberibacter' species associated with HLB. The bioinformatic analysis of the sequences obtained with these primers revealed that all these amplifications came from the presence of other prokaryotic organisms in the samples. The primers developed in this study overcome the problem of undesired amplification in environmental samples. Thus, they could be used in future survey protocols to prevent the eradication of negative trees and the generation of unjustified alarms.

Keywords: undesired amplification; 16S; real-time PCR; sequence identity; greening; HLB; Trioza erytreae; Tamarixia dryi

\section{Introduction}

Accurate detection is one of the benchmarks of plant bacterial disease management. The challenge of detection is greater when the target organism cannot be grown under in vitro conditions, and detection is based only on molecular methods. PCR-based methods have become essential in detection protocols; however, they present problems of sensitivity, specificity and robustness in complex environmental samples such as leaves, roots, insects and soil [1]. Sometimes it is necessary, after designing new primers, to adjust sequences, reagents and amplification conditions to increase the specificity of the reaction as new information becomes available [2]. One plant disease that can serve as a paradigm for detection problems is huanglongbing (HLB), the most devastating disease affecting many citrus species $[3,4]$. 
HLB is associated with three Gram-negative species of bacteria restricted to phloem sieve tubes. These bacteria cannot be grown in the laboratory in pure culture at present. The three presumptive species are ' $\mathrm{C}$. Liberibacter asiaticus' ( $\mathrm{CaLas}$ ), widespread in Asia and America, mainly transmitted by Diaphorina citri Kuwayama (Hemiptera: Liviidae) [5,6]; 'Ca. Liberibacter africanus' (CaLaf), mainly restricted to Africa and transmitted by Trioza erytreae (del Guercio) [7] (Psylloidea: Triozidae) [8,9]; and 'Ca. Liberibacter americanus' (CaLam), only known from Brazil and transmitted by D. citri $[10,11]$. HLB is not reported. however, in important citrus producing areas such as Mediterranean countries, Peru or Australia. In these regions, the disease represents the most serious threat to the citrus industry. The early detection, eradication of infected trees, and control of vectors are the best measures to avoid the entry and spread of HLB-associated bacteria. In the case of vectors, biological and chemical control are the most implemented strategies [12]. Biological control is mainly based on the use of hymenopteran ectoparasitoids Tamarixia radiata (Waterston) (Hymenoptera: Eulophidae) and T. dryi (Waterston) against D. citri and T. erytreae, respectively [13-16]. In 2014, T. erytreae was recorded in mainland Europe: northwest Spain and Portugal along the Atlantic coast, and in recent years it has reached the vicinity of Lisbon. Following these detections, contingency plans, control, and eradication programs have been developed in Spain [17] and Portugal to prevent the spread of this vector and achieve an early detection of HLB-associated bacteria.

Available HLB detection protocols depend on bacterial and vector species. In Mediterranean countries, the European and Mediterranean Plant Protection Organization (EPPO) established a diagnostic standard [18], sharing protocols that also appear in the Draft Annex to ISPM 27: 'Ca. Liberibacter' spp. on Citrus spp. (2004-010) of the International Plant Protection Convention of FAO (IPPC-FAO). In a first step, the recommended protocol aims at the rapid and sensitive detection of all bacteria of the genus ' $\mathrm{Ca}$. Liberibacter' [19] as a screening test. In a second step, PCR protocols are directed to the specific detection of $\mathrm{CaLas}, \mathrm{CaLaf}$ or $\mathrm{C} a \mathrm{Lam}$ in those samples that become positive in the first step [6,11,20-22]. Both stages target sequences of 16S rDNA gene, commonly used worldwide in the PCRs developed for the detection of the most widespread HLB-associated species, CaLas [23].

Other primers and probes based on other genes, such as $r p o B$ and $r p l J / r p l K$ [24-26], have been designed, but the great advantage of the standard 16S rDNA target is that three copies are present in the genome of ' $\mathrm{Ca}$. Liberibacter' species (CaLspp) $[27,28]$, which favors the higher sensitivity of the protocol. However, the use of these $16 \mathrm{~S}$ sequences has the potential risk of false positive amplifications due to their highly conserved nature [23,29-31]. Other primers, RNRf/RNRr, based on a five-copy ribonucleotide reductase gene (nrdB) [32], showed higher detection sensitivity than Li et al. [21] for CaLas detection; nevertheless, it is also a conserved gene among all bacterial species.

In the present study, we developed a methodology for solving the problems of undesired amplifications obtained by two real-time PCR protocols for HLB diagnosis [18]. It is based on the results of a survey carried out with more than four thousand samples that included citrus plant and insect material (psyllids and their parasites). In addition, we propose a complementary method for accurate discrimination between true and false positives based on a simple and cheaper conventional sequencing, with the goal of avoiding false positives.

\section{Materials and Methods}

\subsection{Plant Material}

A total of 2783 samples of asymptomatic plants from the Rutaceae family were analyzed for the diagnosis of HLB (Table 1). Most of them came from surveys conducted in Spain between 2009 and 2018.

Carrot plant material infected with 'Ca. Liberibacter solanacearum' (CaLso) was used as a positive control for the protocol by Bertolini et al. [19]. Three extracts of healthy citrus plant material spiked with synthetic dsDNA gBlocks Gene Fragments synthesized by Integrated DNA Technologies, Inc. (IDT, Iowa, USA) containing the targets of CaLas, CaLam 
and $\mathrm{CaLaf}$ in the PCR by Li et al. [21] were used as the respective positive controls. Healthy plant material from different citrus species, from Instituto Valenciano de Investigaciones Agrarias, IVIA (Valencia, Spain) greenhouses, were used as negative controls.

Table 1. Analysis of plant and insect samples in the period 2009-2018 for the detection of huanglongbing (HLB)-associated bacteria by the real-time PCR protocols described by Bertolini et al. [19] and Li et al. [21].

\begin{tabular}{|c|c|c|c|c|c|c|c|}
\hline \multicolumn{2}{|c|}{ Source } & \multirow[t]{2}{*}{ Origin } & \multirow[t]{2}{*}{$\begin{array}{l}\text { Number Total } \\
\text { Samples }\end{array}$} & \multirow{2}{*}{$\begin{array}{c}\begin{array}{c}\text { Number Positive } \\
\text { Samples by } \\
\text { Bertolini et al. [19] }\end{array} \\
\text { CaLspp }\end{array}$} & \multicolumn{3}{|c|}{$\begin{array}{c}\text { Number of Positive } \\
\text { Samples by Li et al. }\end{array}$} \\
\hline & & & & & CaLam & CaLas & CaLaf \\
\hline \multirow{4}{*}{ Plant } & \multirow{2}{*}{ Citrus sp. } & Spain & 2780 & 210 & 0 & 0 & 3 \\
\hline & & Thailand & 1 & 1 & 1 & 1 & 0 \\
\hline & \multirow{2}{*}{ Murraya koenegii } & Netherlands & 1 & 1 & 0 & 0 & 0 \\
\hline & & Uganda & 1 & 1 & 1 & 0 & 0 \\
\hline Psyllid & Trioza erytreae & Spain $^{\mathrm{a}}$ & 1051 & 9 & 0 & 0 & 0 \\
\hline \multirow{4}{*}{ Parasitoid } & \multirow{4}{*}{ Tamarixia dryi } & South Africa & 82 & 25 & 0 & 0 & 0 \\
\hline & & $\begin{array}{l}\text { Spain }^{\mathrm{a}} \\
\text { (Isoline F1) }\end{array}$ & 317 & 57 & 0 & 0 & 0 \\
\hline & & $\begin{array}{c}\text { Spain }^{\text {a }} \\
\text { (Isoline F2-4) }\end{array}$ & 596 & 142 & 0 & 0 & 2 \\
\hline & & $\begin{array}{c}\text { Spain a } \\
\text { (Isoline F5-9) }\end{array}$ & 86 & 13 & 0 & 0 & 5 \\
\hline Total & & & 4915 & 459 & 2 & 2 & 10 \\
\hline
\end{tabular}

\subsection{Insect Material}

A total of 2132 insect samples from the classical biological control program developed to introduce T. dryi into mainland Europe were selected for HLB diagnosis (Table 1). Of these, 1081 samples were specimens of T. dryi. Eighty-two were collected in Pretoria (South Africa), and the rest belonged to different generations of the colony established at Instituto Canario de Investigaciones Agrarias, ICIA (Canary Islands, Spain) (F1; F2-4; F5-9). The other 1051 samples were T. erytreae individuals obtained from colonies established in a greenhouse maintained on young lemon trees cv. Eureka grafted on HLB-free Citrus macrophylla rootstocks at ICIA. The identification of both insect species was performed by PCR amplification and the sequencing of the mitochondrial COI gene according to Folmer et al. [33].

\subsection{DNA Extraction from Plant Material and Insects}

For the analysis of the plant material, three biological replicates from each sample were placed in separate plastic bags and stored at $4{ }^{\circ} \mathrm{C}$ prior to analysis, according to EPPO protocol [18]. Midribs of the leaves were crushed into extraction bags (Bioreba), using a Homex 6 homogenizer (Bioreba), in PBS extraction buffer at 1:5-10 (w/v). A $1.5 \mathrm{~mL}$ aliquot of each crude plant extract was either processed immediately by real-time PCR or stored at $-20{ }^{\circ} \mathrm{C}$ until use. For the analysis of the insect material, individual specimens were preserved in 70\% ethanol until analysis. Total DNA was obtained from $200 \mu \mathrm{L}$ of crude plant extract or insect material using CTAB (Cetyl Trimethyl Ammonium Bromide) extraction method [18]. The purified DNA was analyzed immediately or preserved at $-20^{\circ} \mathrm{C}$ until use. 


\subsection{Detection of 'Ca. Liberibacter' spp.}

Two protocols, based on real-time PCRs with targets in the $16 \mathrm{~S}$ rDNA gene, were used for the detection of HLB-associated-'Ca. Liberibacter' spp. following EPPO [18]: (1) real-time PCR with universal primers and a TaqMan probe for all CaLspp according to Bertolini et al. [19]; and (2) three real-time PCRs, also using a TaqMan probe, for the specific identification of $\mathrm{Ca}$ Laf, $\mathrm{CaLam}$ and $\mathrm{CaLas}$, as described by Li et al. [21]. Three replicates were included for each sample. StepOne Plus (Applied Biosystems, Foster City, CA, USA) or LightCycler ${ }^{\circledR} 480$ (Roche) thermocyclers were used for the amplification and management of data and analyses.

\subsection{Verification of Positive Samples}

To determine the status of positive with respect to HLB-associated bacteria, a set of primers for conventional PCR were designed in the 16s rDNA gene: CalsppF-sec, $5^{\prime}$ GAG AGT TTG ATC CTG GCT CA $3^{\prime}$ and CalsppR-sec, $5^{\prime}$ TCC TCT CAG ACC AGC TAT $3^{\prime}$. To this end, the sequence alignment of ten reference whole genomes CaLspp available in the databases [34] was performed (accessed on September 2019). The access numbers of the reference genomes were NC_012985; NC_014774; NC_020549; NC_022793; NZ_AOFG00000000; NZ_AP014595; NZ_CP004021; NZ_CP010804; NZ_CP019958; NZ_CP0 29348. According to this alignment, these primers amplify a DNA fragment of $266 \mathrm{bp}$, including target regions of the two real-time PCR protocols described above (Figure 1). Primers designed were used only to analyze the positive samples by real-time PCRs [19,21], not for CaLspp detection. The reaction mixture contained either $0.5 \mu \mathrm{M}$ of each of the primers, $0.15 \mathrm{mM}$ of $\mathrm{MgCl}_{2}, 0.2 \mathrm{mM}$ of dNTPs, $1 \mathrm{X}$ of $10 \mathrm{x}$ standard reaction buffer and $1 \mathrm{U}$ of DNA polymerase (Biotools). The PCR protocol consisted of one step of $95^{\circ} \mathrm{C}$ for $10 \mathrm{~min}$ followed by 45 cycles of amplification $\left(95^{\circ} \mathrm{C}\right.$ for $15 \mathrm{~s}$ and $55^{\circ} \mathrm{C}$ for $\left.1 \mathrm{~min}\right)$. Conventional PCR products were purified using the QIAquick PCR Purification Kit (Qiagen), and sequencing was performed by Sanger method from two assembled sequences (forward and reverse). Quality of the chromatograms was determined with the package SangeranalyseR, tools for Sanger sequencing data [35] in R software [36]. NCBI BLAST search [37] was used to identify related sequences and homologies. Samples that do not show nucleotide homology with any CaLspp were named undesirable or undesired amplifications.

\subsection{Bioinformatic Analysis of the Sequences}

Geneious Prime 2020 software (Biomatters Ltd., Auckland, New Zealand) was used to calculate the match identity of the probe and primer sequences using as reference the consensus and $\mathrm{CaLaf}$ sequences (NZ_CP004021). The consensus sequence was obtained by a MUSCLE [38] alignment using different bacterial species sequences. These sequences included, on the one hand, species that showed high identity by BLASTn [37] with the undesirable amplifications: Sphingomonas sp. (EU567045); Rhizobium spp. (JX566578.1 and AY599690); one unknown soil bacterium (HQ640720.1); Phyllobacterium sp. (MN810203); five uncultured Rhizobiales bacteria (HG938317; EU812986, KJ664621; LR642383 and DQ303365); a Wolbachia sp. endosymbiont of Drosophila simulans Sturtevant, 1919 (CP003883.1); other two endosymbionts of Porphyroptora polonica L. and Bactericera cockerelli (Šulc) (MT5362 26 and AF263557); Asaia sp. (MN099438) and Ochrobactrum sp. (JX679636). On the other hand, they included five Ca. Liberibacter/Liberibacter representative sequences: CaLam (NC 022793); CaLas (CP004005.1); CaLaf (CP004021); 'Ca. Liberibacter solanacearum' (CP002371.1); and Liberibacter crescens (CP003789.1).

\subsection{Phylogenetic Analysis of the Undesirable Amplifications}

Twelve representative samples with undesired amplifications, including citrus plants, psyllid vectors and parasitoid species, were selected for the phylogenetic analysis. To this end, fragments of $266 \mathrm{bp}$ obtained with Calspp-sec primers were aligned with sequences of bacterial species from GenBank that showed high identity in the BLASTn, as described above. Sequences were aligned with Clustal W Algorithm using Mega X software [39] and 
maximum likelihood tree was obtained selecting the best nucleotide substitution model according to Mega X [39].

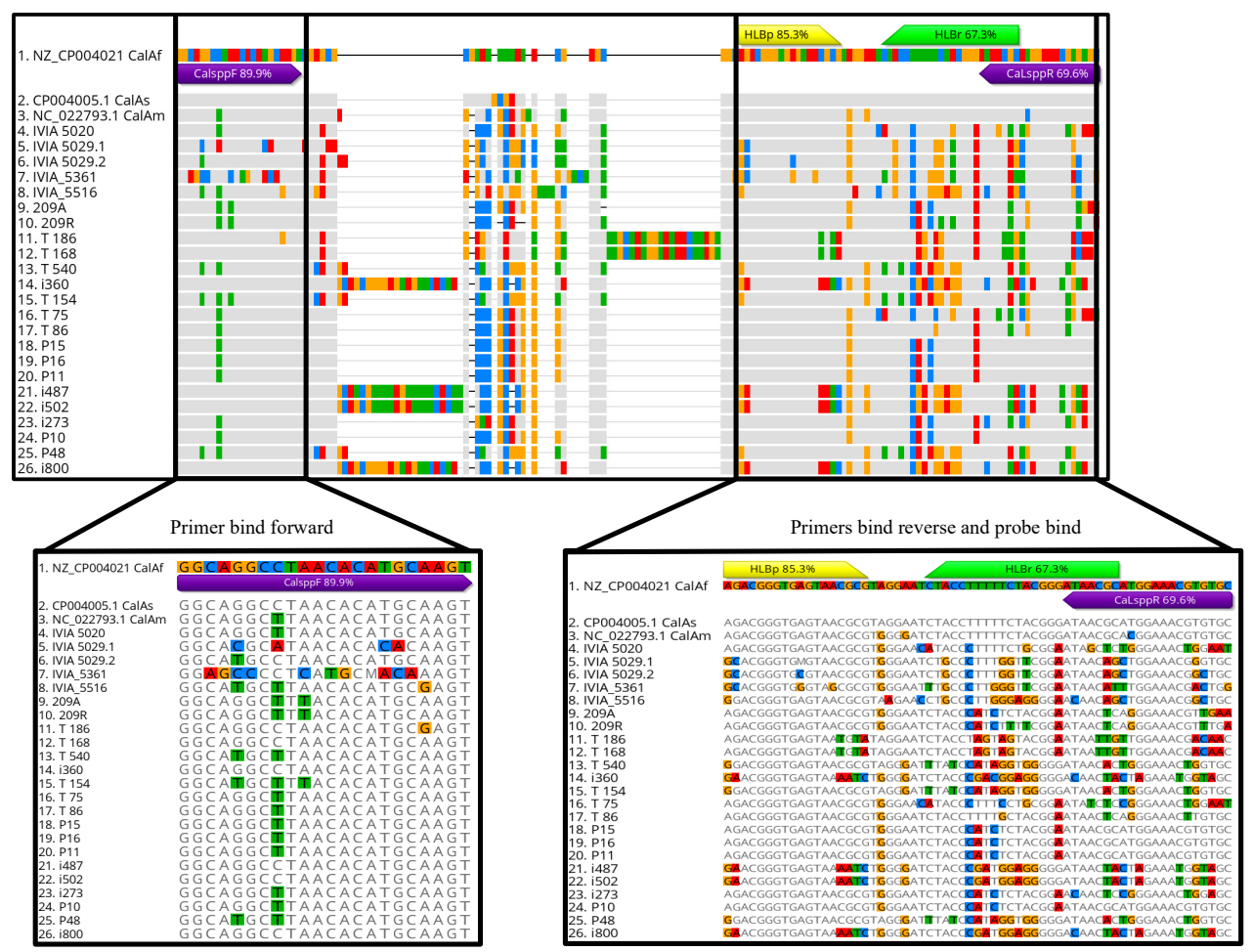

Figure 1. Partial sequence alignment obtained with the primers designed in this study and positioning of the primers described by Bertolini et al. [19] (CalsppR/CalsppF), in purple, Li et al. [21] primer (HLBr) and probe (HLBp), in green and yellow, respectively, within the sequence of 'Candidatus Liberibacter'spp. (CP006604).

\section{Results}

\subsection{Analysis of Plant Samples}

Real-time PCR analyses revealed that 213 out of the 2783 plant samples analyzed (7.65\%) were positive by real-time PCR with the 'Ca. Liberibacter' spp. protocol proposed for the first screening [19] (Table 1). Six samples out of 213 also showed amplification signal with specific HLB primers, but with cycle threshold $(\mathrm{Ct})$ values near the detection limit [21]: sample IVIA 5029.1 from Citrus sp. was positive for both specific primers designed to detect CaLam and CaLas; sample IVIA 5029.2 from Murraya koenigii amplified only with specific primers for CaLam; and sample IVIA 5361 from Citrus unshiu, and P10, P11 and P48 from Citrus sp. only with specific primers for CaLaf (Table 2).

\subsection{Analysis of Insect Samples}

Real-time PCR results of T. erytreae samples showed that nine out of 1051 specimens were positive by the Bertolini et al. PCR [19], representing only the $0.86 \%$ of the field samples and confirming the usefulness of this protocol for the first screening of the HLB vector. The average $\mathrm{Ct}$ value of all insects samples was 33.11, with the minimum value 26.29 and the maximum 35.34. However, the nine samples were negative by Li et al. PCR [21] (Table 1). In the case of T. dryi, 237 out of 1081 (21.92\%) were positive by Bertolini et al. [19] and five of these samples $(0.46 \%)$ also were positive by Li et al. [21] near to its detection limit (Table 1). 
Table 2. Highest sequence identity at the nucleotide level in the GeneBank database of the samples positive by PCR protocols of Bertolini et al. [19] or Li et al. [21].

\begin{tabular}{|c|c|c|c|c|c|c|c|}
\hline \multirow[t]{2}{*}{ Host } & \multirow[t]{2}{*}{ Origin } & \multirow[t]{2}{*}{ Sample } & \multirow{2}{*}{$\begin{array}{l}\text { Real-Time PCR According to } \\
\text { Bertolini et al. [19] } \\
\left(\bar{x}_{\mathrm{Cts}} \pm \mathrm{SD}\right)\end{array}$} & \multicolumn{3}{|c|}{$\begin{array}{l}\text { Real-Time PCR According to Li et al. [21] } \\
\qquad\left(x_{\text {Cts }} \pm \text { SD }\right)\end{array}$} & \multirow{2}{*}{$\begin{array}{l}\text { Sequence Analysis by } n \text { from Checking Sample Results } \\
\text { (Identity\% } \% \text {-GenBank Accession Number) }\end{array}$} \\
\hline & & & & CaLam & CaLas & CaLaf & \\
\hline \multirow{2}{*}{$\begin{array}{l}\text { Murraya } \\
\text { koenegii }\end{array}$} & \multirow{2}{*}{ Uganda } & IVIA 5020 & $34.78 \pm 0.5$ & - & - & - & Rhizobium sp. (98\%-HG938317) \\
\hline & & IVIA 5029.2 & $35.79 \pm 0.7$ & $37.52 \pm 0.1$ & - & - & Sphingomonas sp. (98\%—JX174255.1) \\
\hline \multirow{2}{*}{ Citrus unshiu } & \multirow{2}{*}{$\begin{array}{c}\text { Spain } \\
\text { (main land } \\
\text { Spain) }\end{array}$} & IVIA 5361 & $35.64 \pm 0.2$ & - & - & $36.83 \pm 0.8$ & Sphingomonas sp. (94\%-JX660147) \\
\hline & & IVIA 5516 & $36.22 \pm 0.1$ & - & - & - & Soil bacterium from enrichment culture $(100 \%-\mathrm{HQ} 640720)$ * \\
\hline \multirow{6}{*}{ Citrus spp. } & Thailand & IVIA 5029.1 & $34.48 \pm 0.5$ & $37.89 \pm 0.2$ & $38.47 \pm 0.4$ & - & Sphingomonas sp. (90\%-EU567045.2) \\
\hline & \multirow{5}{*}{$\begin{array}{l}\text { Spain } \\
\text { (Canary } \\
\text { Islands) }\end{array}$} & 209R & $32.82 \pm 0.3$ & - & - & - & Bradyrhizobium sp. (93\%-AY599690). \\
\hline & & 209A & $35.96 \pm 0.5$ & - & - & - & Rhizobiales bacterium (96\%—LR642383.1) \\
\hline & & P10; P11 & $29.48 \pm 0.7$ & - & - & $36.7 \pm 0.3$ & Phyllobacterium sp. $(100 \%-\mathrm{MN} 810203)$ \\
\hline & & P15; P16 & $28.66 \pm 0.7$ & - & - & - & Phyllobacterium sp. (100\%-MN810203) \\
\hline & & P 48 & $37.34 \pm 0.1$ & - & - & $36.50 \pm 0.1$ & Asaia sp. $(99 \%-\mathrm{MN} 099438.1)$ \\
\hline \multirow{5}{*}{ Tamarixia dryi } & \multirow{5}{*}{$\begin{array}{l}\text { South } \\
\text { Africa }\end{array}$} & $\begin{array}{c}\text { T: } 7 ; 31 ; 33 ; 38 ; 46 ; 66 ; 67 ; 147 ; 151 ; \\
\text { 154; 170; 204; 212; 219; } 227 ; 244 ; \\
\text { 247; 257; } 260 ; 267 ; 278\end{array}$ & $34.84 \pm 0.1$ & - & - & - & Asaia sp. $(99 \%-\mathrm{MN} 099438.1)$ \\
\hline & & $\mathrm{T} 75$ & $32.76 \pm 0.8$ & - & - & - & Rhizobium sp. (99\%-JX566578.1) \\
\hline & & $\mathrm{T} 86$ & $33.47 \pm 0.1$ & - & - & - & Ochrobactrum sp. $(100 \%-\mathrm{CP} 015776)$ \\
\hline & & T: $168 ; 186$ & $35.34 \pm 0.1$ & - & - & - & Wolbachia endosymbiont of Drosophila sp. $(99 \%-\mathrm{CP} 034335.1)$ \\
\hline & & T: 540; 555; 567; 575; 576 & $26.29 \pm 1.7$ & ND & - & $35.62 \pm 0.7$ & Asaia sp. $(99 \%-\mathrm{MN} 099438.1)$ \\
\hline \multirow{3}{*}{ Tryoza erytreae } & \multirow{3}{*}{$\begin{array}{l}\text { Spain } \\
\text { (Canary } \\
\text { Islands) }\end{array}$} & i273 & $34.51 \pm 0.5$ & - & - & - & Uncultured bacterium. $(99 \%-\mathrm{KJ} 664621) *$ \\
\hline & & i800; i360 & $35.31 \pm 0.2$ & - & - & - & Sodalis sp. $(91 \%-\mathrm{MT} 536226.1)$ \\
\hline & & i487; i502 & $32.41 \pm 0.6$ & - & - & - & $\begin{array}{l}\text { Secondary endosymbiont of Bactericera cockerelli } \\
(91 \%-\mathrm{AF} 263557.1)\end{array}$ \\
\hline
\end{tabular}

* bacteria not classified according to available databases [34] (accessed on July 2020).

\subsection{Verification of Positive Samples}

3.3.1. Sequence Analyses of the Amplified Fragments

A representative selection of 47 positive samples by the real-time PCRs [19,21] was sequenced in a second round by conventional PCR with the primers designed in this study. These samples included twelve samples from different Rutaceae plant species, thirty from T. dry and five from T. erytreae (Table 2) (GeneBank numbers: MW248533-MW248552). Comparative sequence analyses using BLASTn showed that none corresponded to any species of 'Ca. Liberibacter.' All matched other 16S rDNA genes from other bacteria, so they were non-target amplifications. With respect to Rutaceae plants, samples IVIA 5029.1, IVIA 5029.2 and IVIA 5361 showed the best BLASTn match with Sphingomonas sp., with a sequence identity of 90-98\%. Samples IVIA 5020 and IVIA 5516 presented a sequence identity of $98-100 \%$ with soil bacteria from the Rhizobium genus. Sample 209R showed a 93\% sequence identity with Bradyrhizobium sp., and sample 209A showed a 94\% match with an uncultured bacterium, both of the same order of the Rhizobiales that includes Rhizobium. Samples P10, P11, P15 and P16 presented sequence indentities of 100\% with Phyllobacterium sp; while only one sample, P48, showed an identity of $99 \%$ with uncultured Asaia sp. Twenty-six out of the 30 amplified fragments from T. dryi showed a high sequence identity (99\%) also with Asaia sp. (Table 2). Finally, four samples showed homology with other sequences: two samples with Wolbachia sp. endosymbiont of Drosophila simulans, one sample with the partial sequence of $16 \mathrm{~S}$ rDNA gene of Rhizobium sp. 3041, and one sample with Ochrobactrum pseudogrignonense strain K8. One of the T. erytreae samples, (i273) showed the best BLASTn match with a non-classified uncultured bacterial isolate from soil with a sequence identity of $99 \%$. The remainder of the T. erytreae samples best matched two endosymbionts from other Hemiptera using BLASTn. Specifically, two samples (i800; i360) showed a sequence identity of $91 \%$ with Sodalis sp., an endosymbiont of Porphyrophora polonica L., and the other two (i487; i502) showed a sequence identity of $89 \%$ with a secondary endosymbiont of $B$. cockerelli. 


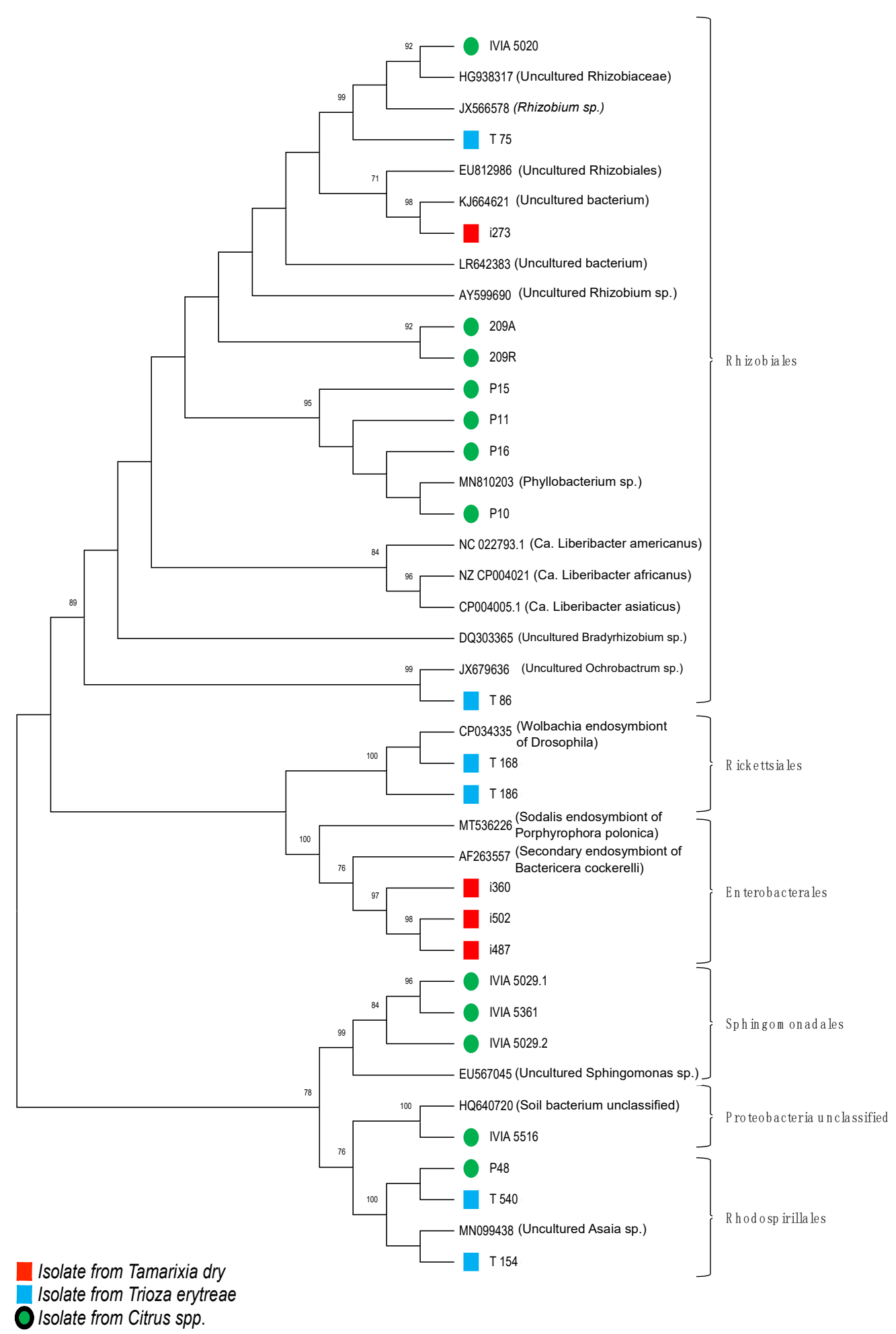

Figure 2. Phylogenetic analysis by the Maximum likelihood method of a fragment of $16 \mathrm{~S}$ ribosomal DNA gene from those samples that were amplified with Bertolini et al. [19] and Li et al. [21] protocols. Trees were generated under the Tamura 3 model [40] of nucleotide substitution. Branches are supported by 1000 bootstrap replicates.

\subsubsection{Phylogenetic Analysis of the Amplifications}

The phylogenetic analysis of the fragments that include the target region of the two real-time PCRs $[19,21]$ confirmed the results obtained by BLASTn searches, demonstrating that the samples with positive results did not match any species of ' $\mathrm{C} a$. Liberibacter' or even 
the clade of this genus (Figure 2). Sequences of both plant and insect material were shown to be clustered into groups of several orders such as Rhizobiales and Sphingomonadales, which include cultured and uncultured bacteria. The insect samples also clustered in the orders of Rickettsiales and Enterobacterales.

\subsubsection{Bioinformatic Analyses of Primers, Probes and Undesired Amplicon Sequences}

To understand the results described above, bioinformatic analyses of primers, probes and undesired amplicon sequences were performed. As shown in Figure 1, the match identity value of the HLBp probe was $85.3 \%$ in the consensus sequence. The match identity of the samples and the HLBp probe sequence was: 100\% for T75, T86, IVIA 5020, i273, P10, P11, P15, P16, 209A and 209R; 95.4\% for T154, T540, P48 and IVIA 5516; 86.3\% for T168, T186, IVIA 5029-1 and IVIA 5029-2; 81.8\% for IVIA 5361; and 72.7\% for i360, i487, i502 and i800.

The match identity value of the HLBr primer was $67.3 \%$ in the consensus sequence. In this case, the sample sequence showed match identity values between 87.5 and $50 \%$. Thus, sample T86 showed a match identity of $87.5 \%$; $83.3 \%$ for P10, P11, P15 and P16; 79.1\% for 209A; 75\% for IVIA 5020 and i273; 70.8\% for 209R and T75; 66.7\% for IVIA 5029-1, IVIA 5029-2, T168 and T186; 58.3\% for IVIA 5361, T154, T540, i487, i502 and P48; 54.2\% for i800; and $50 \%$ for IVIA 5516 and i360 with the HLBp probe sequence.

The match identity value of the CalsppR primer was $69.6 \%$ in the consensus sequence. In this case, the sample sequence showed match identity values between 100 and $57.1 \%$. Thus, the P10, P11, P15 and P16 samples showed a match identity of $100 \%$; $85.7 \%$ for T86; 81\% for IVIA 5029-1 and 209R; 76.2\% for IVIA 5029-2, T154, T540 and P48; 71.4\% for IVIA 5361, IVIA 5516 and 209A; $66.7 \%$ for i273; 62\% for T168, T186, i487 and i502; and 57.1\% for IVIA 5020, T75, i360 and i800 with the HLBp probe sequence.

Match identity value of the CalsppF primer was $89.9 \%$ in the consensus sequence. Samples T168, i360, i487, i502 and i800 showed a match identity of $100 \% ; 95.5 \%$ for IVIA 5020, IVIA 5029-2, T75, T86, T186, P10, P11, P15, P16 and i273; 91\% for 209A, 209R, T540 and P48. 86.3\% for IVIA 5516 and T154; 81.8\% for IVIA 5029-1; and 50\% IVIA 5361 with the HLBp probe sequence.

\section{Discussion}

Accurate and reliable diagnosis, detection, and identification techniques are key elements in the prevention, regulation, and management of the bacterial diseases of plants. A suitable early detection protocol will help to preserve the crops free of pathogenic bacteria and to allow rapid and appropriate responses when they are already present, even in low concentration. Knowledge of how a real-time PCR protocol performs in routine analysis will permit its adequate integration into diagnostic schemes, with the correct interpretation of results, and the design of optimal risk management strategies [41]. Accuracy, sensitivity, and specificity, speed, economy-sustainability, and ease of use are the main characteristics that a detection protocol must meet and knowing the advantages and drawbacks of those used in large-scale surveys is necessary. In this study, we have shown that specificity is particularly important when dealing with varied environmental samples, which have a diverse microbiota that can be mistaken for the target and produce false positive results. There is an increasing number of tools to design specific primers and a growing number of sequences available in databases. However, the absolute specificity of primers or probes is very difficult to achieve and even to predict. In fact, it is estimated that there are between 0.8 and 1.6 million prokaryotic operational taxonomic units (OTUs) worldwide [42]. Therefore, in the design of primers and probes, it is important to take into account both the available sequence databases and the empirical evidence from experimental studies. Extensive surveys and reliable analytical methods are required to demonstrate and confirm the absence of HLB-associated bacteria. In many Mediterranean countries, this work is being carried out using the methodology described for the analysis of plants and vector specimens $[19,21,43]$. To date, the HLB has not been reported in these 
areas, but this situation is subject to change, and optimal detection tools are needed. In the present work, an extensive analysis of Rutaceae host plants, insect vectors and parasitic wasps was carried out following the EPPO protocol for the detection of HLB-associated 'Ca. Liberibacter' spp. [18], using two real-time PCRs targeting the $16 \mathrm{~S}$ rDNA gene [19,21]. Percentages of 7.65 and $2.81 \%$ of the field citrus samples analyzed, from different origins, showed the positive amplification with the genus-specific and species-specific primers, respectively $[19,21]$. In the case of the T. erytreae analysis, less than $1 \%$ of the samples were amplified in the first screening method and none by the PCR specific protocols, confirming the results obtained in previous intensive surveys carried out in Spain [43]. The greatest number of amplifications with universal genus primers $(21.92 \%)$ was obtained in the analysis of specimens of the parasitoid T. dryi, which was not previously tested by the authors of the different evaluated protocols $[19,21]$. This result could be due partly to the genetic relationship of the analyzed specimens, all of them with South African origin. Only 2.95\% tested positive for one of the species-specific protocols [21].

The genus-specific 16S rDNA primers [19] are included in the protocol because of their high sensitivity. In non-HLB endemic areas, it is likely that the pathogenic bacterial population is well below 1.7 cells per phloem cell, which is the concentration assumed in symptomatic plants [44], while the Ct values of asymptomatic samples are expected to have $\mathrm{Ct}$ values no less than 35 [23]. In the present study, the amplification signals were generally obtained at $\mathrm{Ct}$ values above 35 . Although these late values could indicate the presence of the target sequence at low concentration, in more than $97 \%$ of these samples, no amplification was obtained in the second step with the species-specific primers. In a recent work on detection of $\mathrm{CaLas,} \mathrm{Ct}$ values greater than 35 are thought to be due to non-specific sequences of unknown bacteria [23]. Therefore, the signal obtained in the first stage in $9.34 \%$ of the samples suggested undesired amplifications of non-target bacteria with homologies in part of the target sequence of the HLB-associated bacteria.

The lower specificity of the $16 \mathrm{~S}$ rDNA assay has been described as its main drawback $[29,45]$. This is because homologies with sequences from host and/or citrus-associated endophyte organisms [46] compromise a reliable and specific diagnosis of HLB. The verification step developed in this study showed that all positives samples obtained according to the workflow based on two real-time PCRs $[19,21]$ were non-target amplifications not corresponding to the species of ' $\mathrm{Ca}$. Liberibacter'. Among the organisms identified in the analyses of plant samples, it should be noted that Sphingomonas is a genus comprising more than 55 species, some of which inhabit the soil and rhizosphere [47]. Interestingly, the other genus identified in the order Rhizobiales, Phyllobacterium, was phylogenetically close to 'Ca. Liberibacter' [48], and also contains species related to leaves and roots of plants [49]. Since phylogenetic relationships have been found between some metabolically diverse species of Rhizobiales, such as CaLas and Agrobacterium tumefaciens [50,51], it is believed that ' $\mathrm{C}$. Liberibacter' evolved from a common ancestor through diversification and reduction processes, which occurred during the adaptation to the host [52].

In the insect analyses, the amplification with genus-specific $16 \mathrm{~S}$ rDNA primers was obtained in less than $1 \%$ of T. erytreae specimens, in line with a previous work [43]. However, more than $20 \%$ were obtained in the case of the parasitic wasp. Of the T. dryi fragments selected for sequencing, more than $86 \%$ showed a $99 \%$ sequence identity with an uncultured Asaia sp., a genus whose species is frequently associated with plants and insects [53,54], and in fact, this bacterial species also was identified in a citrus sample (P48). From wasp samples, $19 \%$ also were amplified with the CaLaf specific primers. Although the match identity of $\mathrm{CaLaf}$ primers and the probe described by Li et al. [21] was lower than the genus-specific primers described by Bertolini et al. [19], some non-target amplifications could be expected. Other selected spurious amplicons of T. dryi showed 100\% identity with Ochrobactrum pseudogrignonense, a bacterium that can be associated with an insect as an endosymbiont, since the isolation of Ochrobactrum sp. has been reported from the intestinal region of termites, where it participates in the degradation of hemicelluloses [55]. Two other samples of T. dryi revealed sequences like those of the endosymbiont Wolbachia sp., a group of alpha- 
proteobacteria that infect a wide range of insects and filarial nematodes [56]. Wolbachia sp. has been described recently in T. dryi from Kenya [57]. The association of T. dryi with Wolbachia sp. might have important consequences for the classical biological control program, because this bacteria can affect the reproduction of its host [58]. Moreover, a better understanding of the multitrophic interactions between citrus, psyllids, endosymbionts and pathogens could lead to developing more effective management strategies $[56,59,60]$.

Our results show that the non-target amplifications matched the primers and probes. Since the target is a small fragment of a highly conserved gene, $16 \mathrm{~S}$ rDNA, the probability of finding it in prokaryotes that share habitat with HLB-associated bacteria is high, both in citrus and insect hosts. Diagnosis by PCR is based on specific and discriminating sequence signatures. Specificity can be inferred from the comparison of sequences, but discrimination requires empirical evidence [61]. Today, the availability of several ' $\mathrm{C} a$. Liberibacter' genomes allows redefining in silico the specificity of the $16 \mathrm{~S}$ rDNA oligonucleotides. This study shows different bacterial species that share the same habitat as the target organisms (Calspp) and should be considered in the future for the discrimination sequence signatures in the HLB detection by PCR.

Complete genomic sequences of more CaLas, CaLaf and CaLam strains will allow systematic screening of unique genes of HLB-associated bacteria across the genome [26]. Recently, by whole genome sequencing, a missing nucleotide $\mathrm{G}$ was identified in the sequence of the forward primer by Li et al. [21,23]. This made it impossible to distinguish the low CaLas-titer $(\mathrm{Ct}>30)$ from the absence of CaLas in the samples of citrus fruits and the psyllid vector, D. citri [23]. Due to the complexity, the lack of enough knowledge of the plant and insect microbiome, and the limited number of sequences available in the current nucleotide sequence databases of the all HLB-associated ' $C a$. Liberibacter' species, it is not feasible to filter all the possible sequences bioinformatically that could result in false positives. Therefore, a good strategy is to identify undesired amplifications empirically, by combining different sets of primer pairs using a consensus approach [62]. This in silico re-evaluation of the specificity of primers and probes is applicable to many pathogenic bacteria [61], particularly in complex samples such as plant and insect vectors. Sample DNA can be a template for non-specific binding of $C a$ Las primers, forming non-specific products. In the same way host tissues may contain elements that affect the efficiency of the qPCR reaction contributing to the variability of the result, as observed in other environmental samples $[63,64]$.

The accurate identification of HLB-associated bacteria is necessary in all areas where the disease is a major threat to facilitate early identification in plants, insect vectors, and biocontrol agents. Accurate diagnosis assists in the management of HLB-affected trees and the development of HLB-free nursery materials [23,24]. Reliable diagnosis and the differentiation of HLB-associated species also are essential to reduce the spread of this disease through international trade, as well as to minimize the economic impact of possible false positive diagnoses, in particular in non-affected citrus-producing areas such as European Union countries [27]. Although detection based solely on a fragment of the 16S rDNA gene is a valid approach for the rapid screening of samples due to its high sensitivity, for accurate results, the proposed protocol for the sequencing of the amplicons obtained is recommended. Any positives obtained in general surveys should be confirmed with sequence data. That will allow the reliable identification of non-target bacteria and prevent false positive results.

Author Contributions: Conceptualization, F.M., S.B. (Silvia Barbé), E.B., M.M.L., F.S. and E.M.-N.; methodology, F.M., S.B. (Silvia Barbé) and E.M.-N.; formal analysis, F.M., S.B. (Silvia Barbé), F.S. and E.M.-N.; investigation, F.M., S.B. (Silvia Barbé), S.B. (Saskia Bastin), I.N., E.B., E.H.-S. and E.M.-N.; data curation, F.M. and S.B. (Silvia Barbé); writing—original draft preparation, F.M., S.B. (Silvia Barbé) and E.M.-N.; writing—review and editing, F.M., S.B. (Silvia Barbé), E.B., M.M.L., A.U., A.T., F.S. and E.M.-N.; visualization, F.M., S.B. (Silvia Barbé) and E.M.-N.; supervision, M.M.L., A.U., A.T., F.S. and E.M.-N.; project administration, E.M.-N; funding acquisition, M.M.L., A.U., A.T., F.S. and E.M.-N. All authors have read and agreed to the published version of the manuscript. 
Funding: This work was funded by Project TROPICSAFE (Insect-borne prokaryote-associated diseases in tropical and subtropical perennial crops) (grant number 727459) from the European Union's Horizon 2020 research and innovation program and Project E-RTA2015-00005-C06-01 (Métodos de control y contención de Trioza erytreae, vector del huanglongbing de los cítricos from Programa Estatal de I+D+I Orientada a los Retos de la Sociedad) from the Spanish Government.

Institutional Review Board Statement: Not applicable.

Informed Consent Statement: Not applicable.

Data Availability Statement: Not applicable.

Acknowledgments: The authors thank the Spanish Ministry of Agriculture for the support to the National Reference Laboratory of Phytopathogenic Bacteria (IVIA Bacteriology Laboratory) and N.N.A. Tjou-Tam-Sin from the National Reference Centre of The Netherlands for sending some samples. F.E. Morán was the recipient of a fellowship co-funded by the IVIA and the European Social Fund. We would also like to thank the Plant Health Service of the Dirección General de Agricultura del Gobierno de Canarias, which financed the recruitment of S. Bastin for allowing the use of its equipment and facilities.

Conflicts of Interest: The authors declare no conflict of interest.

\section{References}

1. Saingam, P.; Li, B.; Yan, T. Use of amplicon sequencing to improve sensitivity in PCR-based detection of microbial pathogen in environmental samples. J. Microbiol. Methods 2018, 149, 73-79. [CrossRef] [PubMed]

2. Chabbert, E.; Lachaud, L.; Crobu, L.; Bastien, P. Comparison of Two Widely Used PCR Primer systems for detection of toxoplasma in amniotic fluid, blood, and tissues. J. Clin. Microbiol. 2004, 42, 1719-1722. [CrossRef] [PubMed]

3. Bové, J.M. Huanglongbing: A destructive, newly-emerging, century-old disease of citrus. J. Plant Pathol. 2006, 88, 7-37.

4. Ferrarezi, R.S.; Vincent, C.I.; Urbaneja, A.; Machado, M.A. Editorial: Unravelling citrus Huanglongbing disease. Front. Plant Sci. 2020, 11, 1635. [CrossRef] [PubMed]

5. Da Graça, J.V.; Korsten, L. Citrus Huanglongbing: Review, Present status and future strategies. In Diseases of Fruits and Vegetables; Springer: Dordrecht, The Netherlands, 2004; Volume I, pp. 229-245.

6. Jagoueix, S.; Bové, J.M.; Garnier, M. PCR detection of the two 'Candidatus Liberibacter' species associated with greening disease of citrus. Mol. Cell. Probes 1996, 10, 43-50. [CrossRef]

7. Del Guercio, G. Note ed osservazioni di entomologia agraria. Il cecidio delle foglie del limone ed il suo cecidozoo in Eritrea. L'Agricoltura Coloniale 1918, 12, 355-357.

8. McClean, A.P.; Oberholzer, P.C. Citrus psylla, a vector of the greening disease, of sweet orange. S. Afr. J. Agric. Sci. 1965, 8 , 297-298.

9. Planet, P.; Jagoueix, S.; Bové, J.M.; Garnier, M. Detection and characterization of the African citrus greening Liberibacter by amplification, cloning, and sequencing of the rplKAJL-rpoBC operon. Curr. Microbiol. 1995, 30, 137-141. [CrossRef]

10. Yamamoto, P.T.; Felippe, M.R.; Garbim, L.F.; Coelho, J.H.C.; Martins, E.C.; Leite, A.P.R.; Sousa, M.C.; Abrahão, D.P.; Braz, J. Diaphorina citri (Kuwayama) (Hemiptera: Psyllydae): Vector of the bacterium 'Candidatus Liberibacter americanus'. In Proceedings of the Huanglongbing-Greening International Workshop Fundecitrus, Ribeirão Preto, São Paulo, Brazil, 16-20 July 2006.

11. Do Carmo Teixeira, D.; Saillard, C.; Eveillard, S.; Danet, J.L.; da Costa, P.I.; Ayres, A.J.; Bové, J. 'Candidatus Liberibacter americanus', associated with citrus huanglongbing (greening disease) in São Paulo State, Brazil. Int. J. Syst. Evol. Microbiol. 2005, 55, 1857-1862. [CrossRef]

12. Belasque, J.; Bassanezi, R.B.; Yamamoto, P.T.; Ayres, A.J.; Tachibana, A.; Violante, A.R.; Tank, A.; Di Giorgi, F.; Tersi, F.E.A.; Menezes, G.M.; et al. Lessons from huanglongbing management in São Paulo state, Brazil. J. Plant Pathol. 2010, 92, $285-302$.

13. Aubert, B. Trioza erytreae Del Guercio and Diaphorina citri Kuwayama (Homoptera: Psylloidea), the two vectors of citrus greening disease: Biological aspects andpossible control strategies. Fruits 1987, 42, 149-162.

14. Qureshi, J.A.; Rogers, M.E.; Hall, D.G.; Stansly, P.A. Incidence of Invasive (Diaphorina citri) (Hemiptera: Psyllidae) and Its Introduced Parasitoid (Tamarixia radiata) (Hymenoptera: Eulophidae) in Florida Citrus. J. Econ. Entomol. 2009, 102, 247-256. [CrossRef] [PubMed]

15. Pérez-Rodríguez, J.; Krüger, K.; Pérez-Hedo, M.; Ruíz-Rivero, O.; Urbaneja, A.; Tena, A. Classical biological control of the African citrus psyllid Trioza erytreae, a major threat to the European citrus industry. Sci. Rep. 2019, 9, 1-11. [CrossRef] [PubMed]

16. Urbaneja-Bernat, P.; Pérez-Rodríguez, J.; Krüger, K.; Catalán, J.; Rizza, R.; Hernández-Suárez, E.; Urbaneja, A.; Tena, A. Host range testing of Tamarixia dryi (Hymenoptera: Eulophidae) sourced from South Africa for classical biological control of Trioza erytreae (Hemiptera: Psyllidae) in Europe. Biol. Control 2019, 135, 110-116. [CrossRef]

17. Ministerio de Agricultura Alimentación y Medio Ambiente (MAPAMA). Real Decreto 23/2016, de 22 de Enero, por el que se Establece el Programa Nacional de Control y Erradicación de Trioza Erytreae, y el Programa Nacional de Prevención de Diaphorina Citri y 'Candidatus Liberibacter spp'; BOE: Madrid, Spain, 2016; pp. 6432-6441. 
18. European and Mediterranean Plant Protection Organization. PM 7/121 (1) 'Candidatus Liberibacter africanus', 'Candidatus Liberibacter americanus' and 'Candidatus Liberibacter asiaticus'. EPPO Bull. 2014, 44, 376-389. [CrossRef]

19. Bertolini, E.; Felipe, R.T.A.; Sauer, A.V.; Lopes, S.A.; Arilla, A.; Vidal, E.; Mourão Filho, F.A.A.; Nunes, W.M.C.; Bové, J.M.; López, M.M.; et al. Tissue-print and squash real-time PCR for direct detection of 'Candidatus Liberibacter' species in citrus plants and psyllid vectors. Plant Pathol. 2014, 63, 1149-1158. [CrossRef]

20. Teixeira, D.D.C.; Danet, J.L.; Eveillard, S.; Martins, E.C.; De Jesus, W.C.; Yamamoto, P.T.; Lopes, S.A.; Bassanezi, R.B.; Ayres, A.J.; Saillard, C.; et al. Citrus huanglongbing in São Paulo State, Brazil: PCR detection of the 'Candidatus Liberibacter' species associated with the disease. Mol. Cell. Probes 2005, 19, 173-179. [CrossRef]

21. Li, W.; Hartung, J.S.; Levy, L. Quantitative real-time PCR for detection and identification of 'Candidatus Liberibacter' species associated with citrus huanglongbing. J. Microbiol. Methods 2006, 66, 104-115. [CrossRef]

22. Morgan, J.K.; Zhou, L.; Li, W.; Shatters, R.G.; Keremane, M.; Duan, Y.P. Improved real-time PCR detection of 'Candidatus Liberibacter asiaticus' from citrus and psyllid hosts by targeting the intragenic tandem-repeats of its prophage genes. Mol. Cell. Probes 2012, 26, 90-98. [CrossRef]

23. Bao, M.; Zheng, Z.Z.; Sun, X.; Chen, J.; Deng, X. Enhancing PCR capacity to detect 'Candidatus Liberibacter asiaticus' utilizing whole genome sequence information. Plant Dis. 2020, 104, 527-532. [CrossRef]

24. Ananthakrishnan, G.; Choudhary, N.; Roy, A.; Sengoda, V.G.; Postnikova, E.; Hartung, J.S.; Stone, A.L.; Damsteegt, V.D.; Schneider, W.L.; Munyaneza, J.E.; et al. Development of primers and probes for genus and species specific detection of 'Candidatus Liberibacter' species by real-time PCR. Plant Dis. 2013, 97, 1235-1243. [CrossRef] [PubMed]

25. Okuda, M.; Matsumoto, M.; Tanaka, Y.; Subandiyah, S.; Iwanami, T. Characterization of the tufB-secE-nusG-rplKAJL-rpoB gene cluster of the citrus greening organism and detection by loop-mediated isothermal amplification. Plant Dis. 2005, 89, 705-711. [CrossRef] [PubMed]

26. Kogenaru, S.; Yan, Q.; Riera, N.; Roper, M.C.; Deng, X.; Ebert, T.A.; Rogers, M.; Irey, M.E.; Pietersen, G.; Rush, C.M.; et al. Repertoire of novel sequence signatures for the detection of 'Candidatus Liberibacter asiaticus' by quantitative real-time PCR. BMC Microbiol. 2014, 14, 39. [CrossRef] [PubMed]

27. Duan, Y.; Zhou, L.; Hall, D.G.; Li, W.; Doddapaneni, H.; Lin, H.; Liu, L.; Vahling, C.M.; Gabriel, D.W.; Williams, K.P.; et al. Complete genome sequence of citrus huanglongbing bacterium, 'Candidatus Liberibacter asiaticus' obtained through metagenomics. Mol. Plant-Microbe Interact. 2009, 22, 1011-1020. [CrossRef]

28. Kim, J.S.; Wang, N. Characterization of copy numbers of $16 \mathrm{~S}$ rDNA and $16 \mathrm{~S}$ rRNA of 'Candidatus Liberibacter asiaticus' and the implication in detection in planta using quantitative PCR. BMC Res. Notes 2009, 2, 37. [CrossRef]

29. Cellier, G.; Redondo, C.; Cubero, J.; Roselló, M.; de Andrade, E.; Cruz, L.; Ince, E.; Yildiz, H.N.; Güler, P.G.; D'Onghia, A.M.; et al. Comparison of the performance of the main real-time and conventional PCR detection tests for 'Candidatus Liberibacter' spp., plant pathogenic bacteria causing the huanglongbing disease in Citrus spp. Eur. J. Plant Pathol. 2020. [CrossRef]

30. Kunta, M.; Viloria, Z.; del Rio, H.S.; Louzada, E.S. Diverse DNA extraction methods and PCR primers for detection of huanglongbing-associated bacteria from roots of 'Valencia' sweet orange on sour orange rootstock. Sci. Hortic. (Amsterdam) 2014, 178, 23-30. [CrossRef]

31. Louzada, E.S.; Vazquez, O.E.; Braswell, W.E.; Yanev, G.; Devanaboina, M.; Kunta, M. Distribution of 'Candidatus Liberibacter asiaticus' Above and below ground in Texas citrus. Phytopathology 2016, 106, 702-709. [CrossRef]

32. Zheng, Z.; Xu, M.; Bao, M.; Wu, F.; Chen, J.; Deng, X. Unusual five copies and dual forms of $n r d B$ in 'Candidatus Liberibacter asiaticus': Biological Implications and PCR Detection Application. Sci. Rep. 2016, 6, 1-9. [CrossRef]

33. Folmer, O.; Black, M.; Hoeh, W.; Lutz, R.; Vrijenhoek, R. DNA primers for amplification of mitochondrial cytochrome C oxidase subunit I from diverse metazoan invertebrates. Mol. Mar. Biol. Biotechnol. 1994, 3, 294-299.

34. National Center for Biotechnology Information. Available online: https:/ / www.ncbi.nlm.nih.gov/ (accessed on 6 October 2020).

35. Hill, J.T.; Demarest, B.L.; Bisgrove, B.W.; Su, Y.C.; Smith, M.; Yost, H.J. Poly peak parser: Method and software for identification of unknown indels using sanger sequencing of polymerase chain reaction products. Dev. Dyn. 2014, 243, 1632-1636. [CrossRef]

36. Bunn, A.; Korpela, M. A dendrochronology program library in R (dplR9). Dendro 2018, 26, 115-124. [CrossRef]

37. BLAST: Basic Local Alignment Search Tool. Available online: https://blast.ncbi.nlm.nih.gov/Blast.cgi (accessed on 5 October 2020).

38. Edgar, R.C. MUSCLE: A multiple sequence alignment method with reduced time and space complexity. BMC Bioinform. 2004, 5, 1-19. [CrossRef] [PubMed]

39. Kumar, S.; Stecher, G.; Li, M.; Knyaz, C.; Tamura, K. MEGA X: Molecular evolutionary genetics analysis across computing platforms. Mol. Biol. Evol. 2018, 35, 1547-1549. [CrossRef] [PubMed]

40. Tamura, K.; Nei, M.; Kumar, S. Prospects for inferring very large phylogenies by using the neighbor-joining method. Proc. Natl. Acad. Sci. USA 2004, 101, 11030-11035. [CrossRef] [PubMed]

41. López, M.M.; Llop, P.; Olmos, A.; Marco-Noales, E.; Cambra, M.; Bertolini, E. Are molecular tools solving the challenges posed by detection of plant pathogenic bacteria and viruses? Curr. Issues Mol. Biol. 2009, 11, 13-46. [CrossRef]

42. Louca, S.; Mazel, F.; Doebeli, M.; Parfrey, L.W. A census-based estimate of earth's bacterial and archaeal diversity. PLoS Biol. 2019, 17, e3000106. [CrossRef] 
43. Siverio, F.; Marco-Noales, E.; Bertolini, E.; Teresani, G.R.; Peñalver, J.; Mansilla, P.; Aguín, O.; Pérez-Otero, R.; Abelleira, A.; Guerra-García, J.A.; et al. Survey of huanglongbing associated with 'Candidatus Liberibacter' species in Spain: Analyses of citrus plants and Trioza erytreae. Phytopathol. Mediterr. 2017, 56, 98-110. [CrossRef]

44. Tyler, H.L.; Roesch, L.F.W.; Gowda, S.; Dawson, W.O.; Triplett, E.W. Confirmation of the sequence of 'Candidatus Liberibacter asiaticus' and assessment of microbial diversity in huanglongbing-infected citrus phloem using a metagenomic approach. Mol. Plant-Microbe Interact. 2009, 22, 1624-1634. [CrossRef]

45. Damsteegt, V.D.; Postnikova, E.N.; Stone, A.L.; Kuhlmann, M.; Wilson, C.; Sechler, A.; Schaad, N.W.; Brlansky, R.H.; Schneider, W.L. Murraya paniculata and related species as potential hosts and inoculum reservoirs of 'Candidatus Liberibacter asiaticus', causal agent of huanglongbing. Plant Dis. 2010, 94, 528-533. [CrossRef]

46. Lin, H.; Doddapaneni, H.; Bai, X.; Yao, J.; Zhao, X.; Civerolo, E.L. Acquisition of uncharacterized sequences from 'Candidatus Liberibacter', an unculturable bacterium, using an improved genomic walking method. Mol. Cell. Probes 2008, $22,30-37$. [CrossRef] [PubMed]

47. Oyaizu-Masuchi, Y.; Komagata, K. Isolation of free-living nitrogen-fixing bacteria from the rhizosphere of rice. J. Gen. Appl. Microbiol. 1988, 34, 127-164. [CrossRef]

48. Wang, J.; Haapalainen, M.; Schott, T.; Thompson, S.M.; Smith, G.R.; Nissinen, A.I.; Pirhonen, M. Genomic sequence of 'Candidatus Liberibacter solanacearum' haplotype C and its comparison with haplotype A and B genomes. PLoS ONE 2017, 12, e0171531. [CrossRef] [PubMed]

49. Mantelin, S.; Fischer-Le Saux, M.; Zakhia, F.; Béna, G.; Bonneau, S.; Jeder, H.; de Lajudie, P.; Cleyet-Marel, J.C. Emended description of the genus Phyllobacterium and description of four novel species associated with plant roots: Phyllobacterium bourgognense sp. nov., Phyllobacterium ifriqiyense sp. nov., Phyllobacterium leguminum sp. nov. and Phyllobacterium brassicacearum sp. nov. Int. J. Syst. Evol. Microbiol. 2006, 56, 827-839. [CrossRef] [PubMed]

50. Hartung, J.S.; Shao, J.; Kuykendall, L.D. Comparison of the 'Candidatus Liberibacter asiaticus' genome adapted for an intracellular lifestyle with other members of the Rhizobiales. PLoS ONE 2011, 6, e23289. [CrossRef] [PubMed]

51. Wang, N.; Trivedi, P. Citrus huanglongbing: A newly relevant disease presents unprecedented challenges. Phytopathology 2013, 103, 652-665. [CrossRef] [PubMed]

52. Toft, C.; Andersson, S.G.E. Evolutionary microbial genomics: Insights into bacterial host adaptation. Nat. Rev. Genet. 2010, 11, 465-475. [CrossRef]

53. Favia, G.; Ricci, I.; Marzorati, M.; Negri, I.; Alma, A.; Sacchi, L.; Bandi, C.; Daffonchio, D. Bacteria of the genus Asaia: A potential paratransgenic weapon against malaria. Adv. Exp. Med. Biol. 2008, 627, 49-59.

54. Yamada, Y.; Katsura, K.; Kawasaki, H.; Widyastuti, Y.; Saono, S.; Seki, T.; Uchimura, T.; Komagata, K. Asaia bogorensis gen. nov., sp. nov., an unusual acetic acid bacterium in the $\alpha$-Proteobacteria. Int. J. Syst. Evol. Microbiol. 2000, 50, 823-829. [CrossRef]

55. Schäfer, A. Hemicellulose-degrading bacteria and yeasts from the termite gut. J. Appl. Bacteriol. 1996, 80, 471-478. [CrossRef]

56. Eleftherianos, L.; Atri, J.; Accetta, J.; Castillo, J.C. Endosymbiotic bacteria in insects: Guardians of the immune system? Front. Physiol. 2013, 46. [CrossRef] [PubMed]

57. Rasowo, B.A.; Copeland, R.S.; Khamis, F.M.; Aidoo, O.F.; Ajene, I.J.; Mohamed, S.A.; Sétamou, M.; Ekesi, S.; Borgemeister, C. Diversity and phylogenetic analysis of endosymbionts from Trioza erytreae (Del Guercio) and its parasitoids in Kenya. J. Appl. Entomol. 2020, jen.12807. [CrossRef]

58. Werren, J.H.; Baldo, L.; Clark, M.E. Wolbachia: Master manipulators of invertebrate biology. Nat. Rev. Microbiol. $2008,6,741-751$. [CrossRef] [PubMed]

59. Hancock, P.A.; Sinkins, S.P.; Godfray, H.C.J. Strategies for introducing Wolbachia to reduce transmission of mosquito-borne diseases. PLoS Negl. Trop. Dis. 2011, 5, e1024. [CrossRef] [PubMed]

60. Tamborindeguy, C.; Huot, O.B.; Ibanez, F.; Levy, J. The influence of bacteria on multitrophic interactions among plants, psyllids, and pathogen. Insect Sci. 2017, 24, 961-974. [CrossRef] [PubMed]

61. Arahal, D.R.; Llop, P.; Pérez Alonso, M.; López, M.M. In silico evaluation of molecular probes for detection and identification of Ralstonia solanacearum and Clavibacter michiganensis subsp. sepedonicus. Syst. Appl. Microbiol. 2004, 27, 581-591. [CrossRef]

62. Pritchard, L.; Holden, N.J.; Bielaszewska, M.; Karch, H.; Toth, I.K. Alignment-free design of highly discriminatory diagnostic primer Sets for Escherichia coli O104:H4 Outbreak Strains. PLoS ONE 2012, 7, e34498. [CrossRef]

63. Coy, M.R.; Hoffmann, M.; Kingdom Gibbard, H.N.; Kuhns, E.H.; Pelz-Stelinski, K.S.; Stelinski, L.L. Nested-quantitative PCR approach with improved sensitivity for the detection of low titer levels of 'Candidatus Liberibacter asiaticus' in the Asian citrus psyllid, Diaphorina citri Kuwayama. J. Microbiol. Methods 2014, 102, 15-22. [CrossRef]

64. Wilson, I.G. Inhibition and facilitation of nucleic acid amplification. Appl. Environ. Microbiol. 1997, 63, 3741-3751. [CrossRef] 